\title{
Insect pest of wheat crop in District Haripur, KPk, Pakistan
}

\author{
saira bibi ${ }^{1}$, FIAZ KHAN ${ }^{1}$, and AQSA REHMAN ${ }^{1}$ \\ ${ }^{1}$ Hazara University
}

May 8, 2020

\begin{abstract}
During the present study the total 23 species of insects were discovered belonging to 8 orders of class Insecta, insects belongs to order Hemiptera was greater in number, mostly there were presences or abundance of larvae's of both moths and butterflies were recorded. the species that were recorded are given in (fig.1)includes Periplaneta Americana, apema pest, ladybird beetel, green vegetable bug, ladybird beetel, specie of lady bird beetle, blue pansy, Nezara viridula, hawk moth larvae, fluffy caterpillar of moth, green bug, beetel, caterpillar, Inchworm, caterpillar, dytiscus marginlis, caterpillar, white fly, caterpillar, cinnbar moth, grasshopper lime butterfly. These insects were mostly recorded during the time of wheat harvesting other types of insects also recorded but not shooted.
\end{abstract}

\section{Introduction}

Wheat (Triticum aestivum L) is the most widely grown cereal crop in the world, covering about 237 million hectares annually, accounting for a total of 420 million tones [1], and for at least one-fifth of man's calorie intake [2]. In Pakistan the wheat is an important grain crop which is being grown. It is cultivated during winter cropping season after cultivation of summer crops rice and maize. Pakistan Agriculture Research Council [3]. Published a report that country consumes $120 \mathrm{~kg}$ of wheat per capita per year. Wheat is cultivated by All Provinces of Pakistan, therefore Pakistan in listed in top 10 wheat producing states of the globe, but of increasing population of the country still there is problem to complete the grain prerequisite. Yield and quality of grains of the wheat crop has also many pests which damage it and are responsible for great decrease in yields. Damage to crop is caused by the several species of insects, including various kinds of diseases the weather conditions may also be responsible for yield losses in wheat. Feeding inside the stem or on the leaves of the plant various species of insects have been discovered. Biodiversity is the changes in life, but also presence of same kind of organisms in agroecosystems, generally called as biodiversity[4]. Leafhoppers have a very important place among the insect biogenesis that damage to winter wheat agroecosystems. Worldwide Leafhoppers include about 20000 phytophagous distributed species. Most leafhoppers (Javesella pellucida, Psammotettix alienus, Macrosteles laevis) found on cereals and the first one is a vector for viruses [5]. For the control of insect pests of wheat naturally occurring carnivorous insects are responsible[6]. Dangerously damaging pests of wheat crop are Aphids [7]. To know the yields losses caused by Rhopalosiphum padi Studies have been done (L.), Metopolophium dirhodum (Wlk.) and Sitobion avenae (Fab.) [8].By thirps to wheat crops Significant damages have been caused, the development of wheat nearly overlaps thirps life cycle [8]. A strong background can be given by accurate identification of insect species can give and to know the phylogenetic patterns, diversity and the process of evolution and extermination among and between various species. Proper identification of species permits for comparison or expansion of more ancient research works. Due to large number of insect pest invading wheat crop and causing losses in production, it was felt necessary to observe the current insect pest status on wheat crop in district Haripur, growers to diagnose insect pests and find its solution to increase their crop yields the available knowledge will be helpful for the wheat cultivators.

\section{Materials and methods}


Present study was conducted in district Haripur during the wheat season from the agricultural lands from January 2018 to May 2018. Specimens were carried out towards the department of zoology hazara university Mansehra to entomology Labe for further identification and examination. Specimens were collected by using sweep net, pooter and pitfall traps from selected wheat field. Collected Specimens were killed in a jar containing potassium cyanide and mounted through entomological pins, further specimens were labeled. Up to the species level, specimens were identified by the using keys and previous publications.

\section{Results}

During the present study the total 23 species of insects were discovered belonging to 8 orders of class Insecta, insects belongs to order Hemiptera was greater in number, mostly there were presences or abundance of larvae's of both moths and butterflies were recorded. the species that were recorded are given in (fig.1)includes Periplaneta Americana, apema pest, ladybird beetel, green vegetable bug, ladybird beetel, specie of lady bird beetle, blue pansy, Nezara viridula, hawk moth larvae, fluffy caterpillar of moth, green bug, beetel, caterpillar, Inchworm, caterpillar, dytiscus marginlis, caterpillar, white fly, caterpillar, cinnbar moth, grasshopper lime butterfly. These insects were mostly recorded during the time of wheat harvesting other types of insects also recorded but not shooted. The best thing which I observed these caterpillars were the food for the birds as they see them emerging they eat them. Under family Cicadellidae, Collection of leafhoppers revealed the occurrence of 3 species Latreille 1802 subfamily Deltocephalinae, Balclutha incisa (Matsumura, 1902) Fieber 1869 and tribe Macrostelini, Kirkaldy 1906; Psammotettix emarginata under tribe Paralimnini Distant,1908. True bugs were found with 3 species Scotinophara limosa, Leach, Oxycarenus hyalinipennis also recorded. One moth and one grasshopper also recorded. 


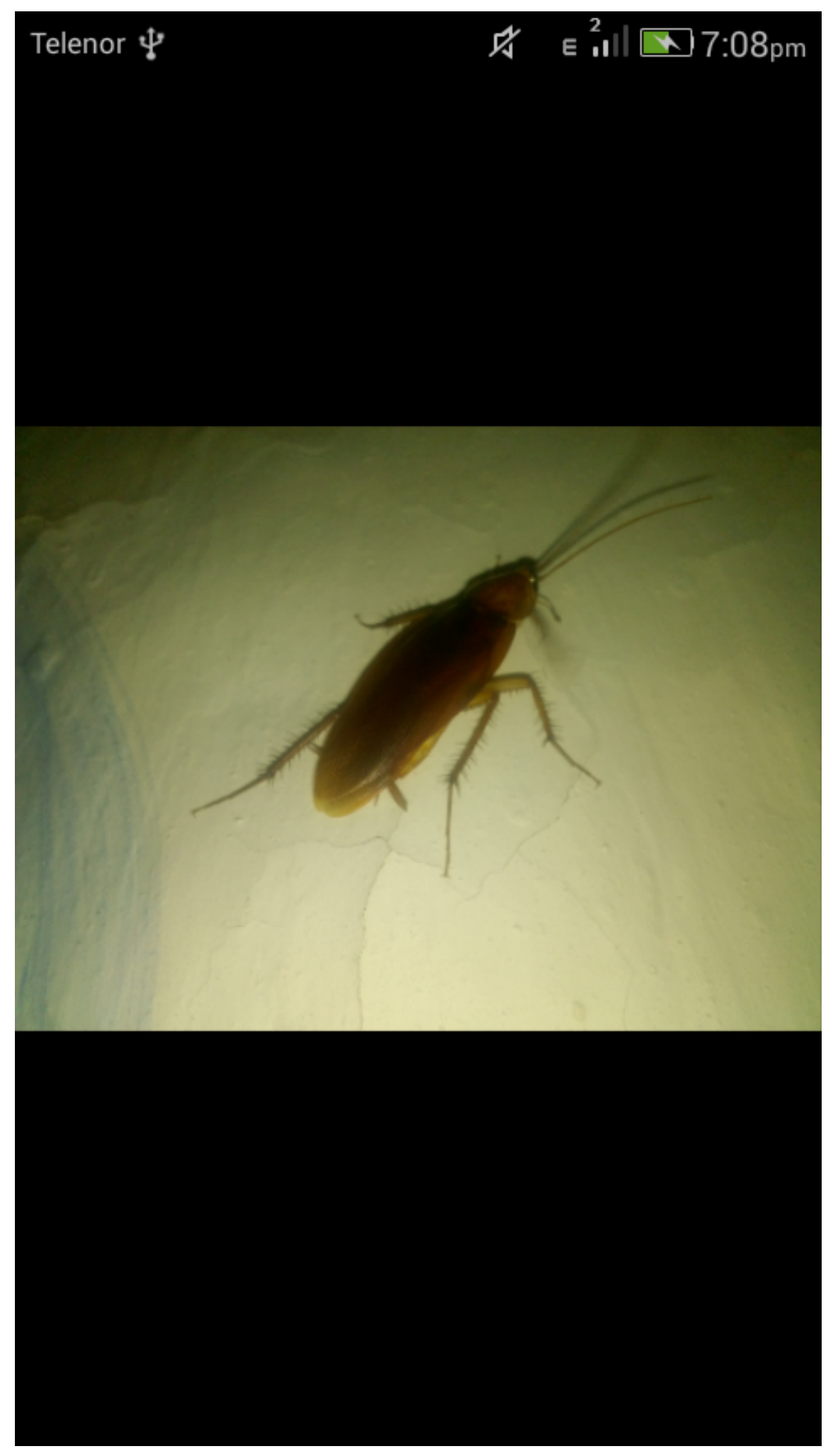




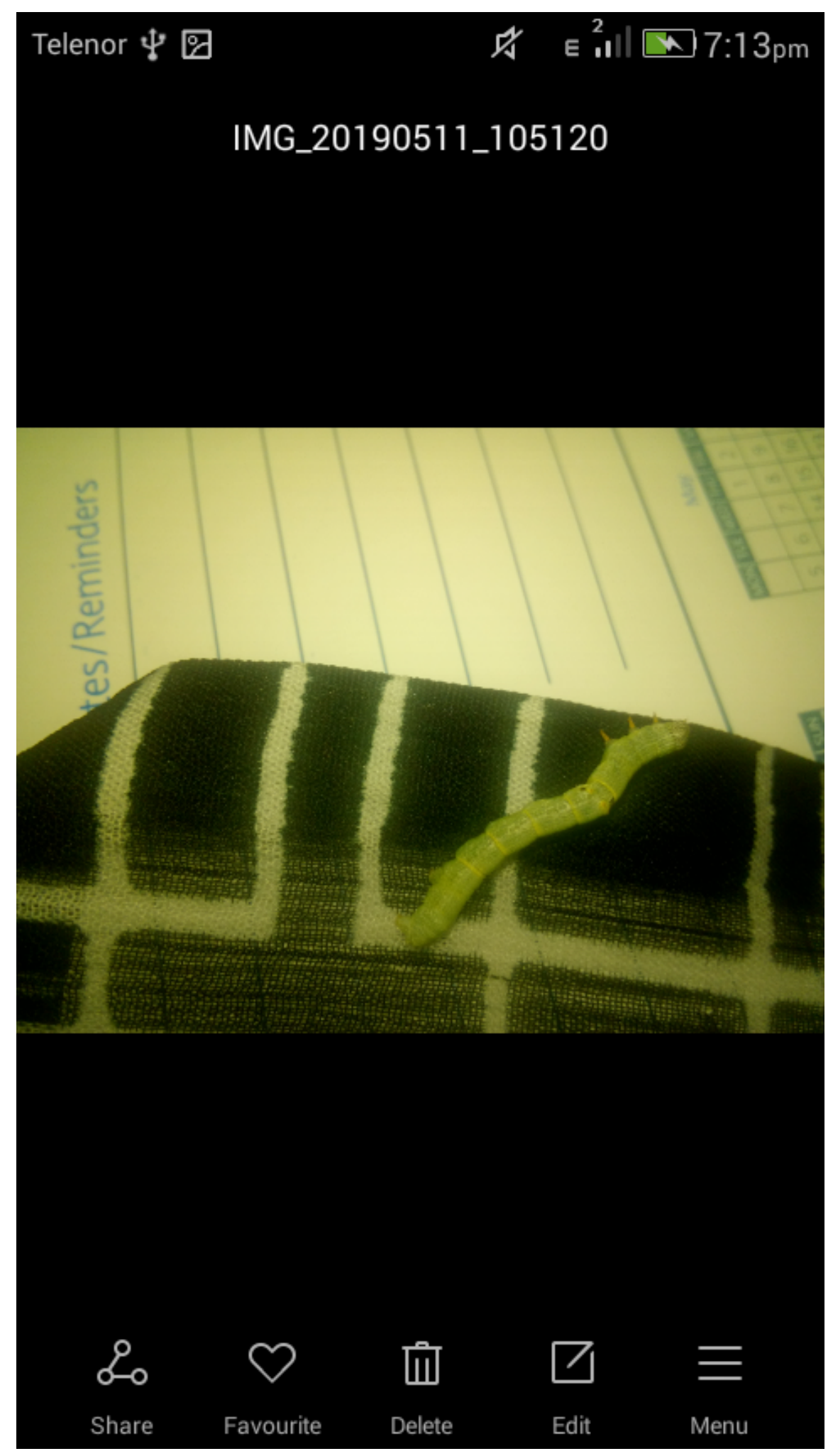

Discussion 
on wheat crop Insect biodiversity earlier was not considered as a harmful element, but due to the recent changes in climate and introduction of new varieties several insects are recorded on wheat crop in district Haripur, there was a big loss to wheat crop this year due to attack of armyworm Some insects are common visitors of wheat crop including aphids, but they usually been under check by their natural enemies as they voraciously fed by coccinellids and Chrysoperla. In present study only the identification of insect pest species were considered. The crop has two critical periods of being attacked by insects' first headling and other is flowering phases [9]. Thirps have been recorded to cause damage [10]. But no thirps have been recorded here so for. Leafhoppers are known as bio indicators and include about 20000 species worldwide[11]. The majority of leafhoppers found on cereals and some are vector for viruses [12]. In present research grasshopper species acrida exaltata under family Acrididae has been found [13].

\section{Data Accessibility Statement}

Data is available in this manuscript should be assesible

\section{Competing Interests}

Authors have no competing interest

\section{Author Contributions}

All authors equally contributed in manuscript

\section{Funding information}

No funding received by any source

\section{Acknowledgments}

I would like to aknowledge my co authors

\section{Data Availability Statement}

The authors confirm that the data supporting the findings of this study are available within the article its supplementary materials

1. OYEWOLE, C., Department of Crop Production, Faculty of Agriculture, Kogi State University, PMB 1008, Anyigba, Kogi State, Nigeria.

2. Ohiagu, C., Storage of food grains in the savannah zones of Northern Nigeria. Food Grain Production in Semi-arid Africa. Menyonga, JM, Bezunah, T. and Youdeowei, A.(eds). Safgrad, Ouagadougou, 1987: p. 361-368.

3. Sacks, W.J., et al., Crop planting dates: an analysis of global patterns. Global Ecology and Biogeography, 2010. 19 (5): p. 607-620.

4. Brohi, M.U., et al., Insect pests of wheat crop at Tandojam. 2019.

5. Carter, N., Management of cereal aphid (Hemiptera: Aphididae) populations and their natural enemies in winter wheat by alternate strip spraying with a selective insecticide. Bulletin of entomological research, 1987. 77 (4): p. $677-682$.

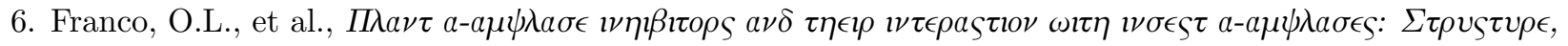

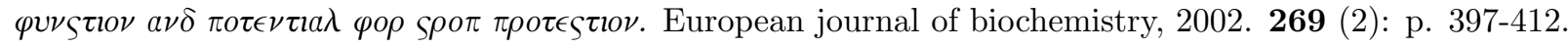

7. Summers, C.G., Potential new insect pests of forage crops in California. Univ. Calif. Plant Prot. Q, 2006. 16 : p. $1-9$.

8. Jones, M.G., The arthropod fauna of a winter wheat field. Journal of applied Ecology, 1976: p. 61-85.

9. Satterthwait, A., Important sunflower insects and their insect enemies. Journal of Economic Entomology, 1948. 41 (5): p. 725-731. 
10. Boonham, N., et al., The detection of Tomato spotted wilt virus (TSWV) in individual thrips using real time fluorescent RT-PCR (TaqMan). Journal of virological methods, 2002. 101 (1-2): p. 37-48.

11. Wheeler, A.G., Biology of the plant bugs (Hemiptera: Miridae): pests, predators, opportunists . 2001: Cornell University Press.

12. Stoner, W.N. and R. Gustin,Biology of Graminella nigrifrons (Homoptera: Cicadellidae), a vector of corn (maize) stunt virus. Annals of the Entomological Society of America, 1967. 60 (3): p. 496-505.

13. Paulraj, M.G., V. Anbalagan, and S. Ignacimuthu, Distribution of Grasshoppers (Insecta: Orthoptera) among different host plants and habitats in two districts of Tamil Nadu, India. Journal of threatened Taxa, 2009: p. 230-233. 